\title{
WestVirginiaUniversity
}

THE RESEARCH REPOSITORY @ WVU

Graduate Theses, Dissertations, and Problem Reports

2005

\section{America and China: Cultural differences in online learning motivation}

\section{Zongxiang Mei}

West Virginia University

Follow this and additional works at: https://researchrepository.wvu.edu/etd

\section{Recommended Citation}

Mei, Zongxiang, "America and China: Cultural differences in online learning motivation" (2005). Graduate Theses, Dissertations, and Problem Reports. 829.

https://researchrepository.wvu.edu/etd/829

This Thesis is protected by copyright and/or related rights. It has been brought to you by the The Research Repository @ WVU with permission from the rights-holder(s). You are free to use this Thesis in any way that is permitted by the copyright and related rights legislation that applies to your use. For other uses you must obtain permission from the rights-holder(s) directly, unless additional rights are indicated by a Creative Commons license in the record and/ or on the work itself. This Thesis has been accepted for inclusion in WVU Graduate Theses, Dissertations, and Problem Reports collection by an authorized administrator of The Research Repository @ WVU. For more information, please contact researchrepository@mail.wvu.edu. 


\title{
America and China: Cultural Differences in Online Learning Motivation
}

\author{
Zongxiang Mei \\ Thesis submitted to the \\ College of Human Resources and Education \\ at West Virginia University \\ in partial fulfillment of the requirements \\ for the degree of \\ Master of Arts \\ in \\ Educational Psychology
}

Floyd L. Stead, Ed. D., Chair

Daniel Hursh, Ph. D.

Neal Shambaugh, Ph. D.

Program of Educational Psychology

Morgantown, West Virginia

2005

Keywords: Online Learning, Motivation, Cultural Difference Copyright 2005 Zongxiang Mei 


\begin{abstract}
America and China: Cultural Differences in Online Learning Motivation

Zongxiang Mei
\end{abstract}

There are learning motivation differences among students from different countries. And differences between American and Korean online learners were identified. This study was to identify whether American and Chinese online learners' motivation differed and what were the learner characteristics that affected the motivation of online learners. This study was conducted in May-June, 2005, West Virginia University, the United States of America, and Fudan University, China. Findings revealed that there was a significant difference in learning motivation between the U.S. and Chinese online learners. And there were some learner characteristics affected the learning motivation of online learners as well, such as gender and employment status. Future research could explore the scope of cultural contexts on a more multileveled area. 


\section{ACKNOWLEDGEMENTS}

Throughout my two and a half years at the Program of Educational Psychology of WVU, I was reminded that the greatest asset you could ever have is people who believe in you and help you. I would like to thank my advisor and committee chair, Larry, Stead, for believing in me and help me during my pursuit of a Master's degree. You gave me confidence and support to stick with my thesis and freedom to excel at my academic pursuit. I could not thank you enough for you undivided attention, patience, and continued support throughout my thesis writing experience.

I would also like to thank the other memorable mentors I have had here- Daniel Hursh and Neal Shambaugh. It was a pleasurable and valuable experience to have you as committee members and spend time exchanging ideas with you.

I would especially like to thank Ming Fang, the Senior Secretary of Youth Studies Center of Fudan University, China. Your support propelled me through the survey in China.

Of course, I could never thank my parents, Yuan Zhao and Zuquan Mei, enough for supporting me through everything I do. Thank you for allowing me to make it this far that you gave me both good genes and great support to let me get so far away from home! I love you both so much.

I also need to thank my husband, Fei Xue, for encouraging me and helping me realize how great it feels to be loved. During my thesis writing process, your patience and never ending supporting are great appreciated.

In the end, thank all of you. 


\section{TABLE OF CONTENTS}

\begin{tabular}{|c|c|}
\hline ABSTRACT & ii \\
\hline ACKNOWLEDGEMENTS & iii \\
\hline CHAPTER ONE & 1 \\
\hline Introduction & 1 \\
\hline CHAPTER TWO & 3 \\
\hline Literature Review & 3 \\
\hline Online learning & 3 \\
\hline Cultural differences on motivation & 4 \\
\hline Motivation & 7 \\
\hline Theoretical framework of motivation & 9 \\
\hline CHAPTER THREE & 12 \\
\hline Methodology & 12 \\
\hline Design & 12 \\
\hline Participants & 12 \\
\hline Instrument & 13 \\
\hline Implementation & 14 \\
\hline CHAPTER FOUR & 16 \\
\hline Results & 16 \\
\hline Participant Profile & 16 \\
\hline National Differences & 18 \\
\hline Individual Level Differences & 19 \\
\hline CHAPTER FIVE & 28 \\
\hline Conclusions and Discussion & 28 \\
\hline National Differences in Online Learning Motivation & 28 \\
\hline Individual Level Differences & 28 \\
\hline Implications & 30 \\
\hline Limitations and Future Research & 31 \\
\hline APPENDIX I & 33 \\
\hline Cover Letter & 33 \\
\hline APPENDIX И & 34 \\
\hline Questionnaire in English & 34 \\
\hline APPENDIX Ш & 37 \\
\hline Questionnaire in Chinese & 37 \\
\hline REFERENCES & 40 \\
\hline
\end{tabular}




\section{CHAPTER ONE}

\section{Introduction}

The development of information technology industry has an important impact on education. At the same time application of online technology in education has grown rapidly in recent years globally. As a developing country, China is practicing integrating technology into education in several universities of big cities as Shanghai, Beijing and Guangzhou. Several universities build Network Education/ Distance Learning/ E-learning College to provide more methods and choices for learning by computer through intranet or internet. Even some middle schools have online education websites and facilities to help students learning after school. Although online courses are brand new for students and education in China, there are a lot of practices to learn from developed country and to pursue a suitable method especially targeted for Chinese students and education in China.

There are many research studies about the application of online learning. Researches have reported the learning motivation in the traditional classroom settings. However, with the trend in online education, research has focused on the learning about learner motivation with online learning. Laszlo and Kuprotz (2003) examined online learning motives by online students in human resource development at an American major land grant university. Course relevance received the strongest agreement as a learning motive followed by self-competence, reinforcement, course interest and last, personal feelings and emotions. Of these learning motives, receiving frequent instructor feedback and course materials that arouse curiosity received the strongest agreement by the online students. Lim (2004) stated globalization and technology are two of the many drivers that impact today's education, locally and internationally. He did a comparison between Korea and the US online learners to identify how they perceived online 
learning motivation differently and what learner characteristics and cultural orientation affected the online learner's learning motivation. Findings revealed that there was a significant difference in learning motivation between the US and Korean online learners. And there were group level and individual level characters affected online learning motivation.

The purpose of this study was to identify whether online learners in China and the America perceive online learning motivation differently and what cultural differences and learner characteristics affect the online learners' learning motivation. The research hypothesis was:

H0: There is no difference in motivation between Chinese and American cultural background for online learning.

H1: Chinese online learners' score of learning motivation is significantly higher or lower than American online learners'.

The independent variable is culture issue as American and Chinese culture. The dependent variable is online learning motivation. 


\section{CHAPTER TWO}

\section{Literature Review}

Online learning

Online learning is defined as content presented via a computer over the Internet or an intranet (an online system accessible only by those within the facility or organization). Like the phrase "E-learning", the term of "online learning" has become very popular. Online learning is a sort of distance learning. With the arrival of the personal computer, the expansion of the internet, and the willingness of national and regional accreditation agencies to consider other than traditional instructional milieus has encouraged the rapid development of online courses (Uhlig, 2002). Online learning shares the common applications of distance education... [as] the following (Newby, Stepich, Lehman, \& Russell ,2000):

- Reaching individuals isolated by distance or geographical barriers

- Reaching nontraditional populations of learners (e.g., adult learners, homebound individuals)

- Providing instruction in specialized subject areas, such as advanced physics or foreign languages, for which a local teacher might not be available

- Bringing experts or other special individuals into the classroom from a distance (e.g., having the author of a children's book interact with a class of elementary students who have just finished reading the book)

- Linking two classrooms together so that students can interact with one another to learn, solve problems, and communicate". 
In the present paper the term of "online learning" is used broadly to refer to almost any learning environment in which electronic media such as computers are used as a component of an instructional delivery system. The benefits of online learning are that learners have control and responsibility for the learning, and the content can be taken whenever a learner has access allowing more flexibility and large amounts of content are broken down into smaller manageable modules. Online learning offers a means of self-directed education with improved learning through interactivity (Benson, 2004).

As the development trend of online learning, National Institute of Corrections (NIC) had started to experiment with merging e-learning and instructor-led instructional strategies into a blended approach to training delivery (Swisher \& Whitfield, 2005). They estimated the next generation is such blended learning.

Hamilton-Pennell (2002) stated that online professional development technology will continue to improve, and it will undoubtedly offer new and exciting options, especially in the area of interactive multimedia. Course developers, however, must learn to make the best use of technology to design courses that are instructionally sound, allow for individualized learning, involve some level of give-and-take, and incorporate effective assessment and evaluation.

Cultural differences on motivation

The most concentrated cross-cultural research on learning pertains to achievement motivation and related learning $(\mathrm{Li}, 2002)$. And the researches below show that there are diverse ways in which people from different cultures are motivated to learn.

In Wilson's (2001) study, Japan is strongly a mono-cultural country. Schooling, though 
prized, is also vilified as an "examination hell" that promotes rote learning of facts and curbs individuality and creativity. Japanese schools communicate a "hidden" message that if you want to succeed in life you must score highly in school examinations by the age of 18 . The premium on academic success in rote-learning educational model is perceived to be inimical to the development of attitudes to learning required for society of the twenty-first century. Watkins and Biggs (1996) noted that students from many Asian countries (particularly those from Confucian heritage culture) have been outperforming students from Western countries both in studies making comparisons across nations as well as where Asian students have studied in Western countries, as migrants or international students. Here the countries of "Confucian-heritage cultures" (CHC) mainly are Japan, China, Taiwan, Singapore, Hong Kong and Korea.

In Salili's (2001) book, Sandra Graham had a program of research on achievement patterns of ethnic minority youth from a motivational perspective. The focus of the research is motivational processes in African American youth. There are several conclusions of these studies. Minority girls at all age levels showed a consistent pattern of admiring, respecting, and wanting to be like high achievers, and even minority boys in the elementary grades showed this same pattern of value preferences. There were complex Ethnicity * Gender * Age interactions when studying achievement values and these interactions highlighted some of the problems faced by adolescent ethnic minority males. Minority adolescent boys contended with the dual stressors of academic difficulty and the widespread negative stereotypes about their group. In this respect they were exceptional individuals whose experiences were both unique and illustrative of the diverse factors that can shape achievement strivings.

Ying-yi Hong did a study about Chinese students' and teachers' inferences of effort and ability in Salili's (2001) book. The research question was: Might the effort attribution 
emphasized in Chinese culture render Chinese students more motivated in learning and less vulnerable to helpless achievement patterns? Research findings pertaining to this question are equivocal. While there are many indications of superior academic learning by Chinese students there are also indications that Chinese students tend to feel less competent, less task oriented and more anxious than their Western counterparts. There findings suggested that the link between effort attribution and learning motivation may not be straightforward in Chinese culture. The main results in this research are that while most students in Chinese culture believe in a positive relationship between effort and ability, some of them also believe in a compensatory relationship between effort and ability. These students were likely to be the ones who had low academic performance and levels of deep motivation in learning. Precious research has shown that compared with their Western counterparts, students, teachers, and parents in Chinese culture are more likely to attribute students' poor performance to effort, which should make Chinese students more mastery-oriented and thus more free of learning problems. These students' belief in a compensatory relationship between effort and ability may be a reflection of their experiences in the achievement situation. When teachers are dealing with students with low performance, they may encourage students to work hard but at the same time believe that their poor performance indicates their lack of ability. In sum, Chinese students' success has been explained by their higher effort attributions. On the other hand, the emphasis on effort have led parents and teachers to put pressure on students to study for long hours, and might have to some extent fostered among students perseverance in studying difficult materials.

It has been frequently demonstrated that Asian students are more likely to make effort attributions for an academic setback than American students. Shikanai (1978) found that Japanese college students who were led to believe that they had failed an anagram task were 
most likely to choose "lack of effort" rather than "lack of ability", "task difficulty", or "luck" as the most important cause. In a study of parental beliefs about children's academic performance by Hess, Chih-Mei \& McDevitt (1982), Chinese mothers cited lack of effort as the predominant cause of likely to attribute failure to ability, training, luck, and effort equally. Chinese children have also shown a comparatively stronger interest in increasing their level of competence in a subject, independent of their perception of the adequacy of their current level (Stigler, Smith, \& Mao, 1985), including a willingness to expend effort even when such an expenditure is not, strictly speaking, necessary.

\section{Motivation}

Motivation is relevant to learning because learning is an active process requiring conscious and deliberate activity. For students to derive maximum benefits from school, educators must provide a learning context in which students are motivated to engage actively and productively in learning activities (Stipek, 2002). If we keep culture in mind, a useful functional definition of motivation is to understand it as a natural human process for directing energy to accomplish a goal (Wlodkowski, 1999). There are several learning motivation theories and models.

ARCS models of motivational design. Keller's (1983) research into learning motives and the mechanics of incorporating motivation into instructional design led to the development of the Attention, Relevance, Confidence, and Satisfaction, or ARCS Model of Motivational Design. Keller believes that before an effort can occur, the learner must value the task and believe he or she can succeed. Therefore, the task should be presented in a way that is engaging, relevant, and promotes positive expectations for the successful achievements of the learning objectives (Small, 1997). 
The ARCS Model identifies four essential strategy components for motivating instruction:

- Attention strategies for arousing and sustaining curiosity and interest;

- Relevance strategies that link to learners' needs, interests, and motives;

- Confidence strategies that help students develop a positive expectation for successful achievement;

- Satisfaction strategies provide extrinsic and intrinsic reinforcement for effort (Keller, 1983).

Malone's theory of intrinsically motivating instruction. Another motivation theory is Malone's theory of intrinsically motivating instruction. Self - regulated learning has three main characteristics (Zimmerman,1989, 1990). First, learners find the environment to be intrinsically motivating, that is, they find participating in the activity to be its own reward and do not seek or need external incentives (Deci, 1985; Lepper\&Malone, 1987). Second, self - regulated learners are meta-cognitively active. Learners actively engage in planning and goal setting and are able to monitor and evaluate their own learning. Third, self - regulated learners are behaviorally active in that they take the necessary steps to select and structure the environment to best suit their own learning styles. Learner control is essential for self - regulated learning.

Malone and Lepper (1987) have defined intrinsic motivation more simply in terms of what people will do without external inducement. Intrinsically motivating activities are those in which people will engage for no reward other than the interest and enjoyment that accompanies them. Malone and Lepper have integrated a large amount of research on motivational theory into a synthesis of ways to design environments that are intrinsically motivating. They subdivide 
factors that enhance motivation into individual factors and interpersonal factors. Individual factors are individual in the sense that they operate even when a student is working alone. Interpersonal factors, on the other hand, play a role only when someone else interacts with the learner.

Theoretical framework of motivation

The theoretical framework of motivation is this study includes relevance, interest, affect, reinforcement, self efficacy and learner control. To specify motivation types valid for online learning, a thorough investigation of learning motivation theory and instrument was conducted.

Relevance.John Keller synthesized existing research on psychological motivation and created the ARCS model (Keller, 1987). In his theory, attention and motivation will not be maintained. However, unless the learner believes the teaching and learning is relevant. Put simply, the teaching should answer the critical question, "What's in it for me?" Benefits should be clearly stated. For a sales training program, the benefit might be to help representatives increase their sales and personal commissions. For a safety-training program, the benefit might be to reduce the number of workers getting hurt. For a software-training program, the benefit to users could be to make them more productive or reduce their frustration with an application.

Interest.Interest can be described as a psychological state that involves focused attention, increased cognitive functioning, persistence, and emotional involvement (Hidi, 2000). The level of interest a student brings to a subject or activity has been shown to affect intrinsic motivation for that task. In the theory of Malone (1981), the intrinsic motivators need to be present to deeply motivate learners as challenge, fantasy and curiosity. High interest in a subject can lead to mastery goals and intrinsic motivation, or mastery goals can lead to high interest and motivation. 
Affect \& emotion. Education is a complicated human behavior. It is hard to be measured directly by linear or quantitive methods. That is because there are affect and emotion among learning and teaching process. Affect, as an intrinsic motivator, is a state of emotional feelings, concerns and passions of individual learner while learning (Wlodkowski, 1999).

Reinforcement. Skinner's theory takes the emphasis on the role of reinforcement in learning. Flowing Skinner's lead, there are many techniques of behavior modification. Students are motivated to complete a task by being promised a reward of some kind. Many times, the reward takes the form of praise or a grade. Sometimes it is a token that can be traded in for some desired object, and at other times the reward may be the privilege of engaging in a self-selected activity. From the behavioral view of motivation, reinforcement desired behavior.

Self-efficacy. It is an individual's estimate or personal judgment of his or her own ability to succeed in reaching a specific goal or a more general goal. Maslow(1987) describes needs hierarchy of 5 levels. The first four needs (physiological, safety, belongingness and love, and esteem) are often referred to as deficiency needs because they motivate people to cat only when they are unmet to some degree. Self-actualization is often called a growth need because people constantly strive to satisfy it. Basically, self-actualization refers the need for self-fulfillment- the need to develop all of one's potential talents and capabilities.

Learner control. Learner control is another motivation factor influencing learner's behavior. Learner control has been an important study subject in the field of instructional systems design and technology(Heinich, 1973; Hoban, 1965; Reigeluth, 1989) Chung and Davis (1995) categorize learner control behaviors into four types: learner control of content, learner control of sequence, learner control of learning pace( time management); and learner control of 
instructional display. Individual learner's control of instruction is inherently appealing to learners, since it is verified that learners are more motivated if they are allowed some control over their own learning. The critical variables that influence learner control decision are the experience of the individual learner and the importance of learning task (Chuang \& Davis, 1995). 


\section{CHAPTER THREE}

\section{Methodology}

Design

This study is to identify whether online learners in China and in the United States of America perceive different motivations to online learning. This relationship is causalcomparative. The null hypothesis states there is no difference in motivation between Chinese and American cultural backgrounds for online learning. The alternative hypothesis states there are different motivations toward online learning by different cultural background. The independent variable are American and Chinese cultures. The dependent variable is online learning motivation.

\section{Participants}

There were a total of 372 students who participated in this survey in the U.S and China. 265 of the participants were undergraduate students. There were a total of 162 American students and 210 Chinese students. For the reason of better comparison, international students in America, graduate students and online learners with web only experiences were excluded from the sample. Included in this sample were 107 American students and 158 Chinese students. The American part of sample consisted of students from West Virginia University. The Chinese participants were students from Fudan University, Shanghai. They participated this survey either by an online survey $(8.68 \%)$ or a paper and pencil questionnaire in classroom $(91.32 \%)$. The demographic information gathered indicates approximately $40.4 \%$ of the respondents are males, $59.6 \%$ females, $14 \%$ are married, $84.9 \%$ are single, and $1.1 \%$ are divorced. Of the respondents, $44.5 \%$ are employed full-time. While $27.5 \%$ are part-time employed, and $27.9 \%$ are not employed. 
Instrument

There are several survey instruments of learning motivation used by educators and researchers. The Instructional Material Motivation Survey (Keller, 1987) and the Motivated Strategies for Learning Questionnaire (Pintrich, Smith, Garcia \& McKeachie, 1993) were mixed used for this study. In 2003, Laszlo, Jr., Kupritz and Lim developed a modified instrument specifically meeting the identified needs of online learning motivation. It is based on the Keller and the Pintrich, Smith, Garcia and McKeachie instruments. A pilot study was conducted to determine item correlation and reliability. Five items were rejected due to respondent misinterpretation or item duplication as determined by item correlation coefficients of $r<.70$. The final instrument consisted of 24 items using a Likert scale ranging from (1) "Strongly Disagree" to (5) "Strongly Agree". Each item was grouped into one of five key learning motives (Laszlo, Jr., Kupritz \& Lim, 2003). The validity of these two surveys has been tested several times in this field. The reliability alpha for each category is as follows:

Overall alpha (.92), Course relevancy (.96), Course interest (.74), Affect/emotion (.53), Reinforcement (.67), Self-efficacy (.83), Learner control (.86). The validity of this study was tested using expert review and correlational analysis from other online learning outcomes conducted in previous studies. In this study, there was a question asking how this survey accurately assesses participants' online learning motivation. And the mean is 3.96 with standard deviation of 0.669 .

With this instrument, Doo Lim (2004) did a study to identify the cross-cultural differences in online learning motivation between Korean and American learners. With permission, this instrument was used to identify the cultural difference between Chinese and American students. There were 6 demographic questions asked in the beginning of survey. They asked about their 
online learning experiences, major, GPA, gender, education level, marital status and employment level. As a result, 32 questions were asked to measure online learners' motivation. Basic descriptive statistics were used to analyze the level of online learning motivation perceived by all students. A T-test was utilized to measure gender difference in the learning motivation. One-way analysis of variance was employed to verify the effect of student characteristics on the learning motivation.

Implementation

In China, this survey was implemented in Fudan University Network Education College in the city of Shanghai by Youth Studies Center. Youth Studies Center of Fudan University is the authorized center for survey in students. In May, 2005, students of Network Education College of Fudan University participated in this questionnaire. May 2005 was still the middle of spring semester in Fudan University and most of the students mixed online classes. That is, students take classes by internet/intranet, but they have opportunities to meet with instructor and classmates in real life as well. The students' majors were Business, Finance, Journalism and Tourism management. A total of 230 paper and pencil questionnaires sent out and 203 questionnaires were collected.

In America, both the online survey and paper and pencil survey were conducted from May to June, 2005. This period is almost the final time of spring semester and summer one semester for WVU students. To keep the similarity of the two samples, paper and pencil survey were better. Some instructors of online courses preferred the online survey for the reason that most online classes do not meet during the final weeks. To get more appropriate participants for this survey, both paper questionnaires in the classroom and online surveys were conducted at West Virginia 
University. During the two months, around 60 instructors were asked to help administer the survey to students. To get the similar study background students, instructors in the College of Business \& Economics, Journalism, Communication, Recreation, Parks and Tourism Resources and the fundamental departments as mathematics and chemistry were asked to help. There were a total of 8 instructors permitted to do surveys in their classes, while 6 instructors shared the online survey link with their students by email. This survey link was also shared and forwarded by email in WVU students to get more participants. There were 217 paper and pencil questionnaires sent out and 122 of them were received. The lower response rate is because not all the classes were online classes and some students have no online learning experiences. On the other hand, there were 40 students who participated in the online survey. So there were a total of 162 American students who participated this survey. 


\section{CHAPTER FOUR}

\section{Results}

In this study, the basic descriptive statistics are used to analyze the level of online learning motivation perceived by all students. SPSS 13.0 (Statistical Package for Social Sciences) was performed to analyze the data. T-tests and one-way ANOVAs were utilized to measure the cultural difference in learning motivation. Six motivation types and the overall motivation were compared. An alpha level of .05 was used for all statistical tests. The data was analyzed as follows.

Participant Profile

Table 1 reports the demographic information of participants by country, which includes gender, education level, marital status, employment status, major and GPA. 
Table 1 Demographic characteristic of respondents

\begin{tabular}{|c|c|c|c|}
\hline \multirow[t]{2}{*}{ Characteristics } & \multicolumn{3}{|c|}{ Number (Percentage) } \\
\hline & Total $(\mathrm{N}=265)$ & U.S.A $(\mathrm{N}=107)$ & China $(\mathrm{N}=158)$ \\
\hline \multicolumn{4}{|l|}{ Gender } \\
\hline Male & $107(40.4)$ & $71(66.4)$ & $36(22.8)$ \\
\hline Female & $158(59.6)$ & $36(33.6)$ & $122(77.2)$ \\
\hline \multicolumn{4}{|l|}{ Education } \\
\hline Undergraduate & $265(100)$ & $107(100)$ & $158(100)$ \\
\hline \multicolumn{4}{|l|}{ Employment status } \\
\hline Full-time & $118(44.5)$ & $7(6.5)$ & $111(70.3)$ \\
\hline Part-time & $73(27.6)$ & $51(47.7)$ & $22(13.9)$ \\
\hline Not employed & $74(27.9)$ & $49(45.8)$ & $25(15.8)$ \\
\hline \multicolumn{4}{|l|}{ Marital status } \\
\hline Married & $37(14.0)$ & $19(17.8)$ & $18(11.4)$ \\
\hline Single & $225(84.9)$ & $87(81.3)$ & $138(87.3)$ \\
\hline Divorced & $3(1.1)$ & $1(0.9)$ & $2(1.3)$ \\
\hline \multicolumn{4}{|l|}{ Major } \\
\hline Tourism & $66(24.9)$ & $29(27.1)$ & $37(23.4)$ \\
\hline Journalism & $46(17.4)$ & $2(1.9)$ & $44(27.8)$ \\
\hline Economics & $47(17.7)$ & $11(10.3)$ & $36(22.8)$ \\
\hline Management & $55(20.8)$ & $14(13.1)$ & $41(25.9)$ \\
\hline Others & $51(19.2)$ & $51(47.7)$ & $0(0)$ \\
\hline \multicolumn{4}{|l|}{ GPA } \\
\hline A & $57(21.5)$ & $23(21.5)$ & $34(21.5)$ \\
\hline $\mathrm{B}$ & $150(56.6)$ & $76(71)$ & $74(46.8)$ \\
\hline $\mathrm{C}$ & $42(15.8)$ & $7(6.5)$ & $35(22.2)$ \\
\hline $\mathrm{D}$ & $16(6)$ & $1(0.9)$ & $15(9.5)$ \\
\hline
\end{tabular}


National Differences

Overall, a significant difference in average motivation score was observed between the two countries $(p<0.05)$. Online students in the U.S. showed a significantly higher motivation mean score than those in China. Table 2 reports the mean scores of the six motivation types. Regarding the importance of each motivation type, course interest and course relevancy marked the highest mean scores followed with reinforcement, self-efficacy, affection and emotion, and learner control. When the six sub-categories of students' motivation mean scores were compared, Chinese students indicated course interest is the highest motivation followed with course relevance, reinforcement, learner control, self-efficacy, then affection and emotion. However American students showed some differences. Course relevancy is the highest motivation, and then followed with course interest, reinforcement, self-efficacy, learner control, affection and emotion. To verify the difference in each motivation type between the U.S. and China, t-test was conducted. Among the six motivation types, course relevancy, reinforcement and self-efficacy were found significantly mean differences between the two countries. And in these three motivation types with significant differences, American students scored higher than Chinese students. There was only one motivation type Chinese students scored higher, that is learner control, which is not significant. 
Table 2Differences in motivation types between countries

\begin{tabular}{|c|c|c|c|c|c|}
\hline Motivation Type & Mean (SD) & Country & $\mathrm{N}$ & $\begin{array}{l}\text { Means for } \\
\text { each country } \\
\text { (SD) }\end{array}$ & T-test p-value \\
\hline \multirow[t]{2}{*}{ Course relevance } & \multirow[t]{2}{*}{$4.02(0.63)$} & US & 107 & $4.20(0.61)$ & \multirow[t]{2}{*}{0.000} \\
\hline & & $\mathrm{CH}$ & 158 & $3.90(0.61)$ & \\
\hline \multirow[t]{2}{*}{ Course interest } & \multirow[t]{2}{*}{$4.03(0.59)$} & US & 107 & $4.09(0.53)$ & \multirow[t]{2}{*}{0.230} \\
\hline & & $\mathrm{CH}$ & 158 & $4.00(0.62)$ & \\
\hline \multirow[t]{2}{*}{ Affect \& emotion } & \multirow[t]{2}{*}{$3.56(0.70)$} & US & 107 & $3.56(0.70)$ & \multirow[t]{2}{*}{0.944} \\
\hline & & $\mathrm{CH}$ & 158 & $3.56(0.70)$ & \\
\hline \multirow[t]{2}{*}{ Reinforcement } & \multirow[t]{2}{*}{$3.86(0.62)$} & US & 107 & $3.99(0.60)$ & \multirow[t]{2}{*}{0.004} \\
\hline & & $\mathrm{CH}$ & 158 & $3.77(0.61)$ & \\
\hline \multirow[t]{2}{*}{ Self-Efficacy } & \multirow[t]{2}{*}{$3.73(0.63)$} & US & 107 & $3.87(0.61)$ & \multirow[t]{2}{*}{0.003} \\
\hline & & $\mathrm{CH}$ & 158 & $3.63(0.63)$ & \\
\hline \multirow[t]{2}{*}{ Learner Control } & \multirow[t]{2}{*}{$3.71(0.76)$} & US & 107 & $3.64(0.84)$ & \multirow[t]{2}{*}{0.196} \\
\hline & & $\mathrm{CH}$ & 158 & $3.76(0.69)$ & \\
\hline \multirow{2}{*}{$\begin{array}{l}\text { Overall } \\
\text { motivation }\end{array}$} & \multirow[t]{2}{*}{$3.82(0.47)$} & US & 107 & $3.89(0.44)$ & \multirow[t]{2}{*}{0.039} \\
\hline & & $\mathrm{CH}$ & 158 & $3.77(0.48)$ & \\
\hline
\end{tabular}

Individual Level Differences

To detect demographic differences, t-test was performed on gender issue. As shown in Table 3 , students in different genders were found have not a significantly difference in overall motivation. But it showed female students have significantly higher motivation mean score for emotion and learner control than male students. Otherwise, male students score higher than female students in course relevance significantly. 
Table 3 Gender differences in motivation types

\begin{tabular}{|c|c|c|c|c|}
\hline Motivation type & Gender & $\mathrm{N}$ & Means (SD) & T-test p-value \\
\hline \multirow[t]{2}{*}{ Course relevance } & Male & 107 & $4.14(0.57)$ & \multirow[t]{2}{*}{0.01} \\
\hline & Female & 158 & $3.94(0.65)$ & \\
\hline \multirow[t]{2}{*}{ Course interest } & Male & 107 & $3.98(0.60)$ & \multirow[t]{2}{*}{0.21} \\
\hline & Female & 158 & $4.07(0.57)$ & \\
\hline \multirow[t]{2}{*}{ Affect \& emotion } & Male & 107 & $3.47(0.71)$ & \multirow[t]{2}{*}{0.09} \\
\hline & Female & 158 & $3.62(0.69)$ & \\
\hline \multirow[t]{2}{*}{ Reinforcement } & Male & 107 & $3.80(0.68)$ & \multirow[t]{2}{*}{0.24} \\
\hline & Female & 158 & $3.90(0.58)$ & \\
\hline \multirow[t]{2}{*}{ Self-Efficacy } & Male & 107 & $3.79(0.63)$ & \multirow[t]{2}{*}{0.19} \\
\hline & Female & 158 & $3.69(0.63)$ & \\
\hline \multirow[t]{2}{*}{ Learner Control } & Male & 107 & $3.60(0.82)$ & \multirow[t]{2}{*}{0.05} \\
\hline & Female & 158 & $3.79(0.70)$ & \\
\hline \multirow[t]{2}{*}{ Overall motivation } & Male & 107 & $3.80(0.48)$ & \multirow[t]{2}{*}{0.525} \\
\hline & Female & 158 & $3.83(0.46)$ & \\
\hline
\end{tabular}


To identify the influence of employment status (full time, part time, not employed) and marital status (single, married, divorced, widowed), one-way ANOVA was performed on marital and employ issues. The mean scores, their standard deviation and the p-value from the one-way ANOVA are listed in Table 4 and 5. Regarding the influence of employment status, Table 4 showed that mean scores of overall motivation, course relevancy, reinforcement and learner control were significantly different. Then Post Hoc Tests was performed to identify the significant difference is between full time and part time, full time and not employed, or part time and not employed. Turkey HSD showed that there were significant differences for course relevancy between full time and part time, full time and not employed; for reinforcement, the significant difference was between full time and not employed; for self-efficacy, it was between full time and not employed, for learner control, it was between part time and not employed, and for the overall motivation, it was between full time and not employed. 
Table 4 Effect of employment status on online learning motivation

\begin{tabular}{|c|c|c|c|c|}
\hline Motivation type & Employment status & $\mathrm{N}$ & Means (SD) & One-way ANOVA p-value \\
\hline \multirow[t]{3}{*}{ Course relevance } & Full time & 118 & $3.88(0.63)$ & \multirow[t]{3}{*}{0.004} \\
\hline & Part time & 73 & $4.12(0.58)$ & \\
\hline & Not employed & 74 & $4.15(0.63)$ & \\
\hline \multirow[t]{3}{*}{ Course interest } & Full time & 118 & $3.97(0.62)$ & \multirow[t]{3}{*}{0.250} \\
\hline & Part time & 73 & $4.04(0.62)$ & \\
\hline & Not employed & 74 & $4.12(0.49)$ & \\
\hline \multirow[t]{3}{*}{ Affect/emotion } & Full time & 118 & $3.54(0.68)$ & \multirow[t]{3}{*}{0.239} \\
\hline & Part time & 73 & $3.48(0.76)$ & \\
\hline & Not employed & 74 & $3.67(0.67($ & \\
\hline \multirow[t]{3}{*}{ Reinforcement } & Full time & 118 & $3.76(0.55)$ & \multirow[t]{3}{*}{0.023} \\
\hline & Part time & 73 & $3.85(0.77)$ & \\
\hline & Not employed & 74 & $4.01(0.52)$ & \\
\hline \multirow[t]{3}{*}{ Self-efficacy } & Full time & 118 & $3.63(0.64)$ & \multirow[t]{3}{*}{0.051} \\
\hline & Part time & 73 & $3.75(0.64)$ & \\
\hline & Not employed & 74 & $3,86(0.58)$ & \\
\hline \multirow[t]{3}{*}{ Learner control } & Full time & 118 & $3.73(0.71)$ & \multirow[t]{3}{*}{0.013} \\
\hline & Part time & 73 & $3.52(0.88)$ & \\
\hline & Not employed & 74 & $3.88(0.66)$ & \\
\hline \multirow[t]{3}{*}{ Overall motivation } & Full time & 118 & $3.75(0.47)$ & \multirow[t]{3}{*}{0.016} \\
\hline & Part time & 73 & $3.79(0.52)$ & \\
\hline & Not employed & 74 & $3.95(0.39)$ & \\
\hline
\end{tabular}

Table 5 reports the differences for marital status issue. From this one-way ANOVA, it was identified that mean scores of affect and emotion were significantly different among the students group with different marital status (single, married, and divorced). Because in this sample, there was no attendance widowed. So there are just three levels of marital status. Then Post Hoc Tests was performed to identify the significant difference is between single and married, or single and divorced, or married and divorced. Turkey HSD showed that there was significant difference just between married and divorced $(\mathrm{p}=0.031)$. Others were not significant different. 
Table 5 Effect of marital status on online learning motivation

\begin{tabular}{|c|c|c|c|c|}
\hline Motivation type & Employment status & $\mathrm{N}$ & Means (SD) & $\begin{array}{l}\text { One-way } \\
\text { ANOVA p-value }\end{array}$ \\
\hline \multirow{3}{*}{ Course relevance } & Married & 37 & $4.02(0.86)$ & \multirow{3}{*}{0.688} \\
\hline & Single & 225 & $4.02(0.57)$ & \\
\hline & Divorced & 3 & $4.33(1.15)$ & \\
\hline \multirow{3}{*}{ Course interest } & Married & 37 & $3.98(0.71)$ & \multirow{3}{*}{0.448} \\
\hline & Single & 225 & $4.04(0.56)$ & \\
\hline & Divorced & 3 & $4.42(1.01)$ & \\
\hline \multirow{3}{*}{ Affect/emotion } & Married & 37 & $3.42(0.87)$ & \multirow{3}{*}{0.031} \\
\hline & Single & 225 & $3.57(0.67)$ & \\
\hline & Divorced & 3 & $4.50(0.66)$ & \\
\hline \multirow{3}{*}{ Reinforcement } & Married & 37 & $3.89(0.67)$ & \multirow{3}{*}{0.272} \\
\hline & Single & 225 & $3.84(0.61)$ & \\
\hline & Divorced & 3 & $4.42(1.01)$ & \\
\hline \multirow{3}{*}{ Self-efficacy } & Married & 37 & $3.84(0.73)$ & \multirow{3}{*}{0.286} \\
\hline & Single & 225 & $3.70(0.61)$ & \\
\hline & Divorced & 3 & $4.08(1.18)$ & \\
\hline \multirow{3}{*}{ Learner control } & Married & 37 & $3.80(0.85)$ & \multirow{3}{*}{0.719} \\
\hline & Single & 225 & $3.70(0.74)$ & \\
\hline & Divorced & 3 & $3.83(0.76)$ & \\
\hline \multirow{3}{*}{ Overall motivation } & Married & 37 & $3.83(0.59)$ & \multirow{3}{*}{0.252} \\
\hline & Single & 225 & $3.81(0.44)$ & \\
\hline & Divorced & 3 & $4.26(0.96)$ & \\
\hline
\end{tabular}

In the general questions of the survey, this study asked participants major and GPA

additionally. Participants were majored in five categories as Tourism Management, Journalism, Economics, Management and others. The mean scores, their standard deviation and the p-value from the on-way ANOVA are listed in Table 6. From one-way ANOVA, there was significant 
difference among different major students in course interest, reinforcement, self-efficacy, learner control and the overall motivation. Then Post Hoc Tests was performed to identify the significant difference among majors. Turkey HSD showed that, for overall motivation there were significant difference between Economics major and other majors. For course interest, significant differences were found between Tourism Management and Economics students, Journalism and Economics students, Economics and Management students, Economics and other majors' students. That is, for course interest, Economics students showed significant difference from any other major in this study. For reinforcement, participants majored in Management and others were different. For self-efficacy, significant difference were identifies between Tourism Management and other majors' students, Economics and others, Management and other majors students. And for learner control, Tourism Management student were different from other majors students. 
Table 6 Effect of major on online learning motivation

\begin{tabular}{|c|c|c|c|c|}
\hline Motivation type & Major & $\mathrm{N}$ & Means (SD) & $\begin{array}{l}\text { One-way } \\
\text { ANOVA p-value }\end{array}$ \\
\hline \multirow[t]{5}{*}{ Course Relevancy } & Tourism Management & 66 & $4.03(0.67)$ & \multirow[t]{5}{*}{0.102} \\
\hline & Journalism & 46 & $3.94(0.49)$ & \\
\hline & Economics & 47 & $3.88(0.63)$ & \\
\hline & Management & 55 & $4.02(0.58)$ & \\
\hline & Others & 51 & $4.21(0.70)$ & \\
\hline \multirow[t]{5}{*}{ Course Interest } & Tourism Management & 66 & $4.09(0.58)$ & \multirow[t]{5}{*}{0.002} \\
\hline & Journalism & 46 & $4.14(0.45)$ & \\
\hline & Economics & 47 & $3.72(0.68)$ & \\
\hline & Management & 55 & $4.09(0.55)$ & \\
\hline & Others & 51 & $4.09(0.56)$ & \\
\hline \multirow[t]{5}{*}{ Emotion } & Tourism Management & 66 & $3.45(0.76)$ & \multirow[t]{5}{*}{0.100} \\
\hline & Journalism & 46 & $3.77(0.51)$ & \\
\hline & Economics & 47 & $3.44(0.80)$ & \\
\hline & Management & 55 & $3.55(0.62)$ & \\
\hline & Others & 51 & $3.64(0.73)$ & \\
\hline \multirow[t]{5}{*}{ Reinforcement } & Tourism Management & 66 & $3.89(0.67)$ & \multirow[t]{5}{*}{0.021} \\
\hline & Journalism & 46 & $3.89(0.56)$ & \\
\hline & Economics & 47 & $3.73(0.62)$ & \\
\hline & Management & 55 & $3.70(0.60)$ & \\
\hline & Others & 51 & $4.07(0.59)$ & \\
\hline \multirow[t]{5}{*}{ Self-efficacy } & Tourism Management & 66 & $3.67(0.67)$ & \multirow[t]{5}{*}{0.006} \\
\hline & Journalism & 46 & $3.75(0.56)$ & \\
\hline & Economics & 47 & $3.57(0.67)$ & \\
\hline & Management & 55 & $3.65(0.59)$ & \\
\hline & Others & 51 & $4.00(0.57)$ & \\
\hline \multirow[t]{5}{*}{ Learner control } & Tourism Management & 66 & $3.49(0.93)$ & \multirow[t]{5}{*}{0.019} \\
\hline & Journalism & 46 & $3.88(0.55)$ & \\
\hline & Economics & 47 & $3.64(0.79)$ & \\
\hline & Management & 55 & $3.73(0.50)$ & \\
\hline & Others & 51 & $3.90(0.81)$ & \\
\hline \multirow[t]{5}{*}{ Motivation } & Tourism Management & 66 & $3.77(0.52)$ & \multirow[t]{5}{*}{0.007} \\
\hline & Journalism & 46 & $3.89(0.36)$ & \\
\hline & Economics & 47 & $3.66(0.57)$ & \\
\hline & Management & 55 & $3.79(0.34)$ & \\
\hline & Others & 51 & $3.99(0.45)$ & \\
\hline
\end{tabular}

As for the issue of GPA, from one-way ANOVA, it was identified that there were significant difference for students with different GPA levels in course interest, emotion, reinforcement, selfefficacy and overall motivation. Here the GPA was compared by A, B, C, D, and F grade levels. 
Then Post Hoc Tests was performed to identify the significant difference for GPA. Turkey HSD showed for emotion, grade $\mathrm{B}$ and $\mathrm{C}$ were significantly different. For reinforcement, grade $\mathrm{A}$ and D, grade B and C, grade B and D were found different. As self-efficacy, significant difference showed between grade $\mathrm{A}$ and $\mathrm{D}$, grade $\mathrm{B}$ and $\mathrm{D}$. Then as the overall motivation, there was significant different between Grade A and D, between B and C, B and D. The mean scores, their standard deviation and the p-value from the on-way ANOVA are listed in Table 7. 
Table 7 Effect of GPA on online learning motivation

\begin{tabular}{|c|c|c|c|c|}
\hline Motivation type & GPA & $\mathrm{N}$ & Means (SD) & $\begin{array}{l}\text { One-way ANOVA p- } \\
\text { value }\end{array}$ \\
\hline \multirow[t]{4}{*}{ Course Relevancy } & $\mathrm{A}$ & 57 & $4.06(0.66)$ & \multirow[t]{4}{*}{0.118} \\
\hline & $\mathrm{B}$ & 150 & $4.07(0.57)$ & \\
\hline & $\mathrm{C}$ & 42 & $3.85(0.75)$ & \\
\hline & $\mathrm{D}$ & 16 & $3.82(0.57)$ & \\
\hline \multirow[t]{4}{*}{ Course Interest } & $\mathrm{A}$ & 57 & $4.09(0.51)$ & \multirow[t]{4}{*}{0.045} \\
\hline & $\mathrm{B}$ & 150 & $4.09(0.55)$ & \\
\hline & $\mathrm{C}$ & 42 & $3.87(0.66)$ & \\
\hline & $\mathrm{D}$ & 16 & $3.78(0.79)$ & \\
\hline \multirow[t]{4}{*}{ Emotion } & $\mathrm{A}$ & 57 & $3.53(0.70)$ & \multirow[t]{4}{*}{0.012} \\
\hline & $\mathrm{B}$ & 150 & $3.67(0.66)$ & \\
\hline & $\mathrm{C}$ & 42 & $3.34(0.70)$ & \\
\hline & $\mathrm{D}$ & 16 & $3.25(0.89)$ & \\
\hline \multirow[t]{4}{*}{ Reinforcement } & $\mathrm{A}$ & 57 & $3.88(0.51)$ & \multirow[t]{4}{*}{0.000} \\
\hline & $\mathrm{B}$ & 150 & $3.96(0.59)$ & \\
\hline & $\mathrm{C}$ & 42 & $3.63(0.63)$ & \\
\hline & $\mathrm{D}$ & 16 & $3.36(0.82)$ & \\
\hline \multirow[t]{4}{*}{ Self-efficacy } & $\mathrm{A}$ & 57 & $3.81(0.65)$ & \multirow[t]{4}{*}{0.016} \\
\hline & $\mathrm{B}$ & 150 & $3.78(0.63)$ & \\
\hline & $\mathrm{C}$ & 42 & $3.54(0.59)$ & \\
\hline & $\mathrm{D}$ & 16 & $3.41(0.53)$ & \\
\hline \multirow[t]{4}{*}{ Learner control } & $\mathrm{A}$ & 57 & $3.85(0.75)$ & \multirow[t]{4}{*}{0.365} \\
\hline & $\mathrm{B}$ & 150 & $3.71(0.76)$ & \\
\hline & $\mathrm{C}$ & 42 & $3.61(0.82)$ & \\
\hline & $\mathrm{D}$ & 16 & $3.58(0.60)$ & \\
\hline \multirow[t]{4}{*}{ Overall Motivation } & $\mathrm{A}$ & 57 & $3.87(0.40)$ & \multirow[t]{4}{*}{0.001} \\
\hline & $\mathrm{B}$ & 150 & $3.88(0.45)$ & \\
\hline & $\mathrm{C}$ & 42 & $3.64(0.51)$ & \\
\hline & $\mathrm{D}$ & 16 & $3.53(0.51)$ & \\
\hline
\end{tabular}




\section{CHAPTER FIVE}

\section{Conclusions and Discussion}

National Differences in Online Learning Motivation

This study is to identify the differences in motivation types between online learners in America and China and what characteristics affected the online learners' learning motivation. One major finding of this study is that American students indicated significantly higher motivation scores for the overall motivation and three motivation types (course relevance, reinforcement and self-efficacy) than Chinese students. Chinese students scored higher only for learner control, which is not significant. This leads to a meaningful discussion of the influence of different cultural orientation on learner motivation. The three motivation types that American students scored significantly higher than Chinese students can be explained in this regard since the survey questions of the three motivation types were to assess the perceived importance of learning content, learning process and learner's ability. This result is quite similar with Doo Lim's (2004) comparison between American and Korean students. As Chinese students scored higher in learner control, some researchers have assert that Asian students are oriented more toward effort attributions and performance goals, while American students are emphasizing mastery of learning over time and enjoying the learning process itself (Grant \& Dweck, 2001).

Individual Level Differences

Regarding gender difference in computer use, several studies showed that male students have a more positive attitude and higher literacy when using computers than female students (Shashaani, 1994; Bannert and Arbinger, 1996; Brosnan, 1998). On the other hand, Lim (2004) 
found female students scored significantly higher for their control of learning process using computers and the internet than male students. In this study, female students also scored significantly higher in learner control $(\mathrm{p}=0.05)$ than male students. Furthermore, female students also showed significantly higher score in affect and emotion $(\mathrm{p}=0.09)$. But male students scored significantly higher in course relevance. We found the different strong motivation type for different gender here. For male students, course relevance is strong. However, female students care more about emotion and affection. With the popularity of computer and internet in human life globally, female students are encountering less difficulty in computer use now.

There are few studies that examine the issue of employment status. The reason I take it into account is that online learning is more convenient for the non-traditional learners, who are full time or part time employed. In this study, the mean scores of overall motivation, course relevance, reinforcement, and learner control were significantly different. In detail, not employed students scored significantly higher than full time employed students in overall motivation, course relevance, reinforcement, self-efficacy, and learner control. For course relevance, part time employed students scored significantly higher than full time employed students as well. The conclusion is that full time employed students inevitably have less learning motivation. Towards such students groups with less reinforcement, course relevance, self-efficacy, and learner control, different teaching strategies would be applied.

As for marital status, Turkey HSD showed that there was significant difference just between married and divorced $(\mathrm{p}=0.031)$ in affect and emotion. Because there were just four divorced participants in this study, the divorced sample is too small easily leading to bias. The mean of divorced people is 4.50 , and the mean of married is 3.42 . One possible explanation is that the divorced people might have a stronger state of emotional feelings, concerns and passions as an 
intrinsic motivator because they could concentrate more on learning other than family or other social issues. Also, married people pay more concerns and passions to family and/or children.

Implications

Course interest and course relevance received the strongest agreement as learning motivators. Both American students and Chinese students ranked course interest and course relevance as the top two motivation types. Academic institutions are reevaluating their course material confirming that what is being taught is demanded by and useful for students. This finding supports some previous studies (Laszlo \& Virginia, 2003; Lim, 2004). Online education, course interest, and course relevance should remain as guiding issues in course design and offering.

Although affect and emotions received the weakest agreement in this study, incorporating support learning strategies in this area may prove beneficial. Compared to previous studies of online learning, means of affect and emotion in this study is the lowest among the motivation types. Wlodknowski (1999) stated an individual's affection is also influenced by organizational and individual factors such as organizational culture and climate, opinions of co-workers and supervisors, attitude towards change, degrees of frustration, and degree of determination and gratification in utilizing newly acquired knowledge and skills. Regarding online learning settings, there are different organizational culture and climate factors as compared to traditional classroom settings. Students might be less concerned about their peers' opinions and more concern about succeeding a certain level of autonomy. A suggestion for online courses instructors is that end-ofcourse evaluation surveys should be a bit more robust than mere exit surveys. Immediate reactions to the course and its instructor may not be truly indicative, and should be retrieved after some time has passed (Frank Laszlo \& Virginia W, 2003).

Online learning in cross cultural learning environments is one new addition that makes the 
face of learning motivation even more diverse (Lim, 2004). This study supports some findings of previous studies of online learning motivation (Frank Laszlo \& Virginia W, 2003; Lim, 2004) and explores the comparisons to China. This study revealed several meaningful findings in cross cultural online learning motivation. Some of them are common between American and Chinese students. Some reveals the unique character of each individual cultural context.

\section{Limitations and Future Research}

There are a lot of limitations of this study as a master's thesis. A major one is the sample limitation. In the Chinese sample, only four majors at Fudan University provided online learning, which limited the comparison. To get a similar sample in America, there were some participants in other majors excluded from this study. There are studies comparing students from different countries in one certain major. For the reason of globalization, studies that concentrate only on students in a certain major worldwide might be too limited. Furthermore, the study might be biased. Another limitation of the sample is that the participants varied in educational levels. This is the same for the Chinese sample; there is no online course for graduate students. Although there are several WVU graduate students represented in this survey, they were excluded from the study. Although Fudan University in Shanghai, China already has online education, it is still in the process of development. This could be a factor for the difference in online education in both countries.

This instrument may not be sensitive to the fact that statistical significant differences may not perfectly represent the differences in practice. Furthermore, the individual characteristics such as gender, employment status, and major may have effected the results as well.. These factors might account for the limitations of this study.

Related questions and recommendations for future research include broadening the scope of 
this kind of study to more multi-level cultural contexts including national, ethnic, organizational, group and individual level variables. At the least, a study of this kind could be administered throughout Asia to test whether students on the whole have similar online learning motivation. Possibly, comparing traditional learning environments with online learning environments within the same research construct is another research topic of importance. In the end, there could be some cross tab analysis to determine whether there are differences between Chinese and American students with regard to gender, employment status, academic major, or other characteristics. 


\section{APPENDIX I}

\section{Cover Letter}

America and China: Cultural Differences in Online Learning Motivation

This research is to identify whether online learners in China and America perceive online learning motivation differently. This study is a requirement for Master's thesis.

This survey would take your around 10 minutes to complete. The participation in the entire project is voluntary. All the participants completing this survey have the right not to respond to every item, and the confidentiality and anonymity will be maintained. Your class standing or grades would not be jeopardized if you choose not to participate.

Your data will be kept confidential except in cases where the researcher is legally obligated to report specific incidents.

Please call Zongxiang Mei at (304) 296-5822 if you have any questions.

Your help is greatly appreciated and your prompt response will be one of the keys to the successful and timely completion of this study.

Signature

Attachment: Questionnaire 


\section{APPENDIX И}

\section{Questionnaire in English}

\section{Questionnaire of American and China: Cultural Differences in Online Learning Motivation}

General Information:

1. Please select the one best describe your online learning experience

Online learning mixed with real meeting with instructor and/or examination Completely online learning without meeting any instructor or classmate

2. What's your major? GPA?

3. Gender

\begin{tabular}{|c|c|c|c|c|c|c|}
\hline & & & $\square$ & Male & $\square$ & Female \\
\hline & & & $\square$ & Undergraduate & $\square$ & Graduate \\
\hline & $\square$ & Single & $\square$ & Divorced & $\square$ & Widow \\
\hline & $\square$ & Full-Time & $\square$ & Part-Time & $\square$ & Not Employed \\
\hline
\end{tabular}

4. Study Level

5. Marital Status

Full-Time

Select one response that best describes your thoughts or feelings related to each statement using the following scale.

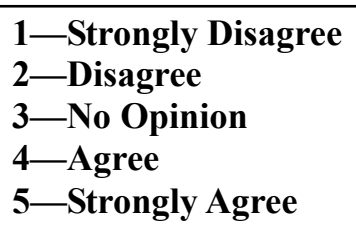

\section{Online Course Relevancy:}

1. It is important for me to learn what is being taught in this course.

2. It is important for me to choose subjects that relate to my studies and/or my job.

3. I believe the materials I am learning will apply to my studies and/or my job.

4. I believe the materials I am learning will support my career goals.

\begin{tabular}{|l|l|l|l|l|}
1 & 2 & 3 & 4 & 5 \\
$\square$ & $\square$ & $\square$ & $\square$ & $\square$ \\
\hline 1 & 2 & 3 & 4 & 5 \\
$\square$ & $\square$ & $\square$ & $\square$ & $\square$ \\
1 & 2 & 3 & 4 & 5 \\
$\square$ & $\square$ & $\square$ & $\square$ & $\square$ \\
1 & 2 & 3 & 4 & 5 \\
$\square$ & $\square$ & $\square$ & $\square$ & $\square$ \\
\hline
\end{tabular}




\section{Course interest:}

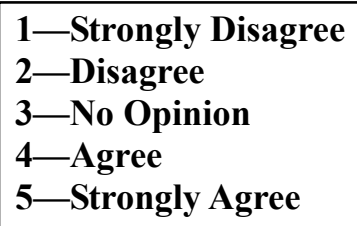

\begin{tabular}{|c|c|c|c|c|c|}
\hline 5. I prefer course material that arouses my curiosity. & $\begin{array}{l}1 \\
\square\end{array}$ & \begin{tabular}{l|}
2 \\
$\square$
\end{tabular} & \begin{tabular}{l|l}
3 \\
$\square$
\end{tabular} & $\begin{array}{l}4 \\
\square\end{array}$ & $\begin{array}{l}5 \\
\square\end{array}$ \\
\hline 6. I often learn new concepts in surprising or unexpected ways. & $\begin{array}{l}1 \\
\square\end{array}$ & $\begin{array}{l}2 \\
\square\end{array}$ & $\begin{array}{l}3 \\
\square\end{array}$ & $\begin{array}{l}4 \\
\square\end{array}$ & \\
\hline $\begin{array}{l}\text { 7. A variety of lesson topics and instructional events help maintain } \\
\text { my attention while studying. }\end{array}$ & $\begin{array}{l}1 \\
\square\end{array}$ & $\begin{array}{l}2 \\
\square\end{array}$ & $\begin{array}{l}3 \\
\square\end{array}$ & $\begin{array}{l}4 \\
\square \\
\end{array}$ & $\begin{array}{l}5 \\
\square \\
\end{array}$ \\
\hline 8. Challenging coursework helps me learn new things. & $\begin{array}{l}1 \\
\square\end{array}$ & $\begin{array}{l}2 \\
\square\end{array}$ & \begin{tabular}{l|l}
3 \\
$\square$
\end{tabular} & $\begin{array}{l}4 \\
\square\end{array}$ & $\begin{array}{l}5 \\
\square\end{array}$ \\
\hline \multicolumn{6}{|l|}{ Affect and Emotion: } \\
\hline $\begin{array}{l}\text { 9. Completing lesson assignments gives me a feeling of } \\
\text { accomplishment. }\end{array}$ & $\begin{array}{ll}1 \\
\square\end{array}$ & $\begin{array}{l}2 \\
\square\end{array}$ & \begin{tabular}{l|l}
3 \\
$\square$
\end{tabular} & $\begin{array}{l}4 \\
\square\end{array}$ & \\
\hline $\begin{array}{l}\text { 10. It is important for me to voice my opinions during class without } \\
\text { fear of embarrassment. }\end{array}$ & $\begin{array}{l}1 \\
\square\end{array}$ & $\begin{array}{l}2 \\
\square\end{array}$ & $\begin{array}{l}3 \\
\square\end{array}$ & $\begin{array}{l}4 \\
\square\end{array}$ & \\
\hline 11. I enjoy learning for learning's sake. & $\begin{array}{l}1 \\
\square\end{array}$ & $\begin{array}{l}2 \\
\square\end{array}$ & $\begin{array}{l}3 \\
\square\end{array}$ & $\begin{array}{l}4 \\
\square\end{array}$ & $\begin{array}{l}5 \\
\square\end{array}$ \\
\hline 12. I often enroll in classes to obtain a sense of belonging. & $\begin{array}{l}1 \\
\square\end{array}$ & $\begin{array}{l}2 \\
\square\end{array}$ & $\begin{array}{l}3 \\
\square\end{array}$ & $\begin{array}{l}4 \\
\square\end{array}$ & \\
\hline
\end{tabular}

\section{Reinforcement:}

\begin{tabular}{|c|c|c|c|c|c|}
\hline 13. It is important for me to receive instructor feedback. & & \begin{tabular}{|l|}
2 \\
$\square$
\end{tabular} & $\begin{array}{l}3 \\
\square\end{array}$ & & \begin{tabular}{|l|}
5 \\
$\square$ \\
\end{tabular} \\
\hline $\begin{array}{l}\text { 14. In the absence of instructor feedback, I use self-praise for work I } \\
\text { do well. }\end{array}$ & $\begin{array}{l}1 \\
\square\end{array}$ & \begin{tabular}{l|l}
2 \\
$\square$
\end{tabular} & $\begin{array}{l}3 \\
\square\end{array}$ & $\begin{array}{l}4 \\
\square\end{array}$ & $\begin{array}{l}5 \\
\square\end{array}$ \\
\hline $\begin{array}{l}\text { 15. It is important for me to know that I can ask fellow students for } \\
\text { help when needed. }\end{array}$ & $\begin{array}{ll}1 \\
\square\end{array}$ & \begin{tabular}{|l|l|l}
2 \\
$\square$
\end{tabular} & \begin{tabular}{l|l}
3 \\
$\square$
\end{tabular} & $\begin{array}{l}4 \\
\square\end{array}$ & \begin{tabular}{l|l}
5 \\
$\square$
\end{tabular} \\
\hline $\begin{array}{l}\text { 16. It is important for me to view my grades frequently as the course } \\
\text { progresses. }\end{array}$ & $\begin{array}{ll}1 \\
\square\end{array}$ & \begin{tabular}{l|l}
2 \\
$\square$
\end{tabular} & \begin{tabular}{l|l}
3 \\
$\square$
\end{tabular} & $\begin{array}{l}4 \\
\square\end{array}$ & $\begin{array}{ll}5 \\
\square\end{array}$ \\
\hline
\end{tabular}

\section{Self-efficacy:}

17. When compared to other students, I am certain that I will do well on the lesson assignments.

18. I believe that I understand the concepts taught in this online course.

19. I utilize effective study skills in learning new concepts.

20. I feel that my personal computer skills are sufficient to successfully complete the lesson assignments.

\begin{tabular}{|l|l|l|l|l|}
1 & 2 & 3 & 4 & 5 \\
$\square$ & $\square$ & $\square$ & $\square$ & $\square$ \\
\hline 1 & 2 & 3 & 4 & 5 \\
$\square$ & $\square$ & $\square$ & $\square$ & $\square$ \\
\hline 1 & 2 & 3 & 4 & 5 \\
$\square$ & $\square$ & $\square$ & $\square$ & $\square$ \\
\hline 1 & 2 & 3 & 4 & 5 \\
$\square$ & $\square$ & $\square$ & $\square$ & $\square$ \\
\hline
\end{tabular}




\section{Locus of Control:}

\begin{tabular}{|c|c|c|c|c|c|}
\hline 21. I remain focused while completing the lesson assignments. & & \begin{tabular}{l|l}
2 \\
$\square$
\end{tabular} & $\begin{array}{l}3 \\
\square\end{array}$ & & $\begin{array}{l}5 \\
\square\end{array}$ \\
\hline 22. I effectively manage my study time. & $\begin{array}{l}1 \\
\square\end{array}$ & 2 & $\begin{array}{l}3 \\
\square\end{array}$ & & $\begin{array}{l}5 \\
\square \\
\end{array}$ \\
\hline $\begin{array}{l}\text { 23. It is important for me to have control over when and where I } \\
\text { study. }\end{array}$ & $\begin{array}{l}1 \\
\square\end{array}$ & 2 & \begin{tabular}{l|l}
3 \\
$\square$
\end{tabular} & $\begin{array}{l}4 \\
\square\end{array}$ & $\begin{array}{l}5 \\
\square\end{array}$ \\
\hline $\begin{array}{l}\text { 24. I always finish my assignments by the due date without } \\
\text { procrastination. }\end{array}$ & $\begin{array}{l}1 \\
\square\end{array}$ & $\begin{array}{l}2 \\
\mathrm{c}\end{array}$ & $\begin{array}{l}3 \\
\square\end{array}$ & $\begin{array}{l}4 \\
\mathrm{c}\end{array}$ & $\begin{array}{l}5 \\
\square\end{array}$ \\
\hline This survey accurately assesses my online learning motivation. & $\begin{array}{ll}1 \\
\square\end{array}$ & $\begin{array}{ll}2 \\
\mathrm{C}\end{array}$ & \begin{tabular}{l|l}
3 \\
$\square$
\end{tabular} & & $\begin{array}{l}5 \\
\square\end{array}$ \\
\hline
\end{tabular}




\section{APPENDIX UI}

\section{Questionnaire in Chinese}

问卷编号：

\section{参加网络教育的中美大学生学习激励调研}

亲爱的同学: 您好!

感谢您愿意参加这次调研。该调研目的是为了解关于网络教育, 中国和美国大学生的学习激励是 否存在文化差异。请您自愿参加问卷调查。我们将严格保密你所提供的任何个人情况, 所有资料仅用 于科学统计分析。该次调查将不会影响您的成绩和考评。

非常感谢您的合作和支持！

梅宗翔

美国西弗吉尼亚大学教

育心理学系

2005-4-4

\section{填写注意事项}

1 ，请你在问卷每个提问后面的回答栏中，选择你认为合适的答案，在其序号的数字下方框打勾。

2 , 除了有特别说明的以外, 请你每个提问只选择1个答案。

首先，请问您的一些基本情况

专业

性别

A 男

B 女

教育程度

口 A 本科生

口 B 研究生

婚姻状况

$\square$ A 已婚

$\square \mathrm{B}$ 未婚

$\square \mathrm{C}$ 离婚

口 D 丧居

工作现状

口 A 全职

成绩绩点

$\begin{array}{lll}\mathrm{A} & \mathrm{B}\end{array} \mathrm{C}$

$\square \mathrm{B}$ 半工半读

口 C 不工作

$\square \mathrm{D}$

下面是关于你参加网络学院课程的问题

请选择最符合你的现状/想法的选项。

$$
\begin{aligned}
& 1 \text { - 强烈反对 } \\
& 2 \text { - 不同意 } \\
& 3 \text { - 无所谓 } \\
& 4 \text { - 同意 }
\end{aligned}
$$


网络课程相关性

\begin{tabular}{|l|}
\hline 1 - 强烈反对 \\
2 - 不同意 \\
3 - 无所谓 \\
4 - 同意
\end{tabular}

\begin{tabular}{|c|c|c|c|c|c|}
\hline 1. 对我而言, 网络学院的授课内容很重要 & $\begin{array}{l}1 \\
\square\end{array}$ & $\begin{array}{l}2 \\
\square\end{array}$ & $\begin{array}{l}3 \\
\square\end{array}$ & $\begin{array}{l}4 \\
\square\end{array}$ & $\begin{array}{l}5 \\
\square\end{array}$ \\
\hline 2. 我认为重要的是选择和我的学业/工作有关的课程。 & $\begin{array}{l}1 \\
\square\end{array}$ & $\begin{array}{l}2 \\
\square\end{array}$ & $\begin{array}{l}3 \\
\square\end{array}$ & $\begin{array}{l}4 \\
\square\end{array}$ & $\begin{array}{l}5 \\
\square\end{array}$ \\
\hline 3. 我相信我现在学习的 (网络课程) 将会运用到我的学业/工作中。 & $\begin{array}{l}1 \\
\square\end{array}$ & $\begin{array}{l}2 \\
\square\end{array}$ & $\begin{array}{l}3 \\
\square\end{array}$ & $\begin{array}{l}4 \\
\square\end{array}$ & $\begin{array}{l}5 \\
\square\end{array}$ \\
\hline 4. 我相信我现在学习的 (网络课程) 讲会对我的职业目标有帮助。 & $\begin{array}{l}1 \\
\square\end{array}$ & $\begin{array}{l}2 \\
\square\end{array}$ & $\begin{array}{l}3 \\
\square\end{array}$ & $\begin{array}{l}4 \\
\square\end{array}$ & $\begin{array}{l}5 \\
\square\end{array}$ \\
\hline
\end{tabular}

\begin{tabular}{|c|c|c|c|c|c|}
\hline 5. 我喜欢能够引起我求知欲的课程。 & $\begin{array}{l}1 \\
\square\end{array}$ & $\begin{array}{l}2 \\
\square\end{array}$ & $\begin{array}{l}3 \\
\square\end{array}$ & $\begin{array}{l}4 \\
\square\end{array}$ & $\begin{array}{l}5 \\
\square\end{array}$ \\
\hline 6. 我经常在学到新知识的时候有惊喜。 & $\begin{array}{l}1 \\
\square\end{array}$ & $\begin{array}{l}2 \\
\square\end{array}$ & $\begin{array}{l}3 \\
\square\end{array}$ & $\begin{array}{l}4 \\
\square\end{array}$ & $\begin{array}{l}5 \\
\square\end{array}$ \\
\hline 7. 在学习时, 多样的课程内容和授课方式让我对课程保持兴趣。 & $\begin{array}{l}1 \\
\square\end{array}$ & $\begin{array}{l}2 \\
\square\end{array}$ & $\begin{array}{l}3 \\
\square\end{array}$ & $\begin{array}{l}4 \\
\square\end{array}$ & $\begin{array}{l}5 \\
\square\end{array}$ \\
\hline 8. 有挑战性的作业能让我学到新东西。 & $\begin{array}{l}1 \\
\square\end{array}$ & $\begin{array}{l}2 \\
\square\end{array}$ & $\begin{array}{l}3 \\
\square\end{array}$ & $\begin{array}{l}4 \\
\square\end{array}$ & $\begin{array}{l}5 \\
\square\end{array}$ \\
\hline
\end{tabular}

\section{情绪}

\begin{tabular}{|l|l|l|l|l|l|}
\hline 9. 完成作业让我有成就感。 & 1 & 2 & 3 & 4 & 5 \\
\hline 10. 对我而言，能大方的在课堂上发表我的观点很重要。 & $\square$ & $\square$ & $\square$ & $\square$ & $\square$ \\
\hline 11. 做为学生，我很享受学习的过程。 & 1 & 2 & 3 & 4 & 5 \\
\hline 12. 我上课的一个原因是课堂让我有归属感。 & $\square$ & $\square$ & $\square$ & $\square$ \\
\hline
\end{tabular}

\section{促进}

13. 能够收到老师的反馈对我很重要。 


\begin{tabular}{|c|c|c|c|c|c|}
\hline 14. 当我表现好，但是老师没有反馈的时候，我会自我表扬来激励自己。 & 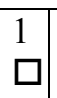 & $\begin{array}{l}2 \\
\square\end{array}$ & $\begin{array}{l}3 \\
\square\end{array}$ & $\begin{array}{l}4 \\
\square\end{array}$ & $\begin{array}{l}5 \\
\square\end{array}$ \\
\hline 15. 很重要的一点是, 我知道, 如果我需要帮助, 我可以向同学寻求帮助。 & $\begin{array}{l}1 \\
\square\end{array}$ & $\begin{array}{l}2 \\
\square\end{array}$ & $\begin{array}{l}3 \\
\square\end{array}$ & $\begin{array}{l}4 \\
\square\end{array}$ & $\begin{array}{l}5 \\
\square\end{array}$ \\
\hline 16. 在学期中可以经常查询成绩很重要。 & \begin{tabular}{l|l}
1 \\
$\square$
\end{tabular} & \begin{tabular}{l|l}
2 \\
$\square$
\end{tabular} & \begin{tabular}{l|l}
3 \\
$\square$
\end{tabular} & $\begin{array}{l}4 \\
\square\end{array}$ & $\begin{array}{l}5 \\
\square\end{array}$ \\
\hline
\end{tabular}

\section{自我认知}

$$
\begin{aligned}
& 1 \text { - 强烈反对 } \\
& 2 \text { - 不同意 } \\
& 3 \text { - 无所谓 } \\
& 4 \text { - 同意 }
\end{aligned}
$$

\begin{tabular}{|c|c|c|c|c|c|}
\hline 17. 和其他同学相比, 我确定我的作业做得很好。 & $\begin{array}{l}1 \\
\square\end{array}$ & $\begin{array}{l}2 \\
\square\end{array}$ & $\begin{array}{l}3 \\
\square\end{array}$ & $\begin{array}{l}4 \\
\square\end{array}$ & $\begin{array}{l}5 \\
\square\end{array}$ \\
\hline 18. 我相信我能理解课程讲的概念。 & $\begin{array}{l}1 \\
\square\end{array}$ & $\begin{array}{l}2 \\
\square\end{array}$ & $\begin{array}{l}3 \\
\square\end{array}$ & $\begin{array}{l}4 \\
\square\end{array}$ & $\begin{array}{l}5 \\
\square\end{array}$ \\
\hline 19. 我用了一些有效的学习方法来学新知识。 & $\begin{array}{l}1 \\
\square\end{array}$ & $\begin{array}{l}2 \\
\square\end{array}$ & $\begin{array}{l}3 \\
\square\end{array}$ & $\begin{array}{l}4 \\
\square\end{array}$ & $\begin{array}{l}5 \\
\square\end{array}$ \\
\hline 20. 我觉得我的电脑知识足够胜任网络课程的作业。 & $\begin{array}{l}1 \\
\square\end{array}$ & $\begin{array}{l}2 \\
\square\end{array}$ & $\begin{array}{l}3 \\
\square\end{array}$ & $\begin{array}{l}4 \\
\square\end{array}$ & $\begin{array}{l}5 \\
\square\end{array}$ \\
\hline
\end{tabular}

\begin{tabular}{|c|c|c|c|c|c|}
\hline 21. 做作业的时候我保持专心。 & \begin{tabular}{l|}
1 \\
$\square$
\end{tabular} & $\begin{array}{l}2 \\
\square\end{array}$ & $\begin{array}{l}3 \\
\square\end{array}$ & $\begin{array}{l}4 \\
\square\end{array}$ & $\begin{array}{l}5 \\
\square\end{array}$ \\
\hline 22. 我能有效的管理我的学习时间。 & $\begin{array}{l}1 \\
\square\end{array}$ & $\begin{array}{l}2 \\
\square\end{array}$ & $\begin{array}{l}3 \\
\square\end{array}$ & $\begin{array}{l}4 \\
\square\end{array}$ & $\begin{array}{l}5 \\
\square\end{array}$ \\
\hline 23. 能够自己分配管理学习时间和地点很重要。 & $\begin{array}{l}1 \\
\square\end{array}$ & $\begin{array}{l}2 \\
\square\end{array}$ & $\begin{array}{l}3 \\
\square\end{array}$ & $\begin{array}{l}4 \\
\square\end{array}$ & $\begin{array}{l}5 \\
\square\end{array}$ \\
\hline 24. 我总能按时完成作业不会拖欠。 & $\begin{array}{l}1 \\
\square\end{array}$ & $\begin{array}{l}2 \\
\square\end{array}$ & $\begin{array}{l}3 \\
\square\end{array}$ & $\begin{array}{l}4 \\
\square\end{array}$ & $\begin{array}{l}5 \\
\square\end{array}$ \\
\hline 25. 此调查准确的衡量了我的网上学习激励。 & \begin{tabular}{l|l}
1 \\
$\square$
\end{tabular} & $\begin{array}{l}2 \\
\square\end{array}$ & $\begin{array}{l}3 \\
\square\end{array}$ & $\begin{array}{l}4 \\
\square\end{array}$ & $\begin{array}{l}5 \\
\square \\
\end{array}$ \\
\hline
\end{tabular}

\section{控制能力}

问卷就此结束, 谢谢合作！ 


\section{REFERENCES}

Benson, E.P. (2004). Online learning: a means to enhance professional development. Critical Care Nurse, 24, 60-63.

Chung, J. \& Davis, IK (1995). An instructional theory for learner control: Revisited, Proceedings of the 1995 Annual National Convention of the Association for Educational Communications and Technology, AECT, Anaheim, CA, 72-86.

Deci, E.L. \& Ryan, R. (1985). Intrinsic motivation and self-determination in human behavior. New York: Plenum.

Hamilton-Pennell, C. (2002). Getting ahead by getting online. Library Journal, 127, 32-35.

Keller, J.M., \& Kopp, T.W. (1987). Application of the ARCS model to motivational design. In C. M. Reigeluth (Ed.), Instructional Theories in Action: Lessons Illustrating Selected Theories. New York: Lawrence Erlbaum, 289 - 320.

Hess, R. D., Chih-Mei, C., \& McDevitt, T. M. (1982). Cultural variations in family beliefs about children's performance in mathematics: Comparisons among People's Republic of China, Chinese-American, and Caucasian-American families. Journal of Educational Psychology, 79(2), 179-188.

Hidi, S. (2000). An interest researcher's perspective: The effets of extrinsic and intrinsic factors on motivation. In C. Sansome and J.M Harackiewicz (Eds.) Intrinsic and Extrinsic Motivation: The Search for Optimal Motivation and Performance. NY: Academic Press.

Hoban, C.F. (1965) From theory to policy decisions, AV Communications Review, 13, 121-139. 
Laszlo, A. \& Castro, K. (1995). Technology and value: Interactive learning environments for future generations. Educational Technology, 35(2), 7-13.

Li, J. (2002). A cultural model of learning: Chinese "heart and mind for wanting to learn" Journal of Cross-cultural Psychology, 33, 248-269.

Lim, D. H. (2004). Cross culture differences in online learning motivation. Educational Media International, 41, 163-173.

Malone, T. (1981). Towards a theory of intrinsically motivating instruction. Cognitive Science, 4, $333-369$

Malone, T. \& Lepper, M. (1987). Making learning fun: A taxonomy of intrinsic motivations of learning. In R. E. Snow \& M. J. Farr (Eds.), Aptitude, learning, and instruction: Vol. 3. Conative and affective process analyses (pp. 223-253). Hillsdale, NJ: Lawrence Erlbaum.

Maslow, A. H. (1954). Motivation and personality. New York: Harper and Row

Newby, T.J., Stepich, D.A., Lehman, J.D., \& Russell, J.D. (2000). Instructional technology for teaching and learning: Designing instruction, integrating computers, and using media. Upper Saddle River, NJ: Prentice-Hall.

Pintrich, P. R., Smith D., Garcia T., \& McKeachie W. (1991). A Manual for the Use of the Motivated Strategies for Learning Questionnaire. Technical Report 91-B-004.

Pintrich, P. R., Smith D., Garcia T., \& McKeachie W. (1993). Reliability and predictive validity of the motivated strategies for learning questionnaire. Educational and psychological Measurement, 53, 801-813

Salili, F., Chiu, C.Y., \& Hong, Y. Y. (2001). Student motivation: the culture and context of learning. New York, Kluwer Academic/ Plenum 
Shikanai, K. (1978). Effects of self-esteem on attribution of success-failure. Japanese journal of Experimental Social Paychology, 18, 47-55.

Small, R. V. (1997). Motivation in instructional design. ERIC Reproductive Document Service, ED409895

Stigler, J. W., Smith, S., \& Mao, L. (1985). The self-perception of competence by Chinese children. Child Development, 56, 1259-1270.

Stipek, D. (2002). Motivation to learn: Integrating theory and practice. Allyn \& Bacon, Boston.

Swisher, S. \& Whitfield, C. (2005). Embracing several generations in distance learning Corrections Today, February, 80-82.

Uhlig, G. E. (n.d.). The present and future of distance learning. Education, 122(4), 670-673.

Watkins, D.A. \& Biggs, J. B. (1999). The Chinese learner: Cultural, psychological and contextual influences. Comparative Education Research Centre (CERC) \& Australian Council of Educational Research (ACER).

Wilson, J. D. (2001). Lifelong learning in Japan--a lifeline for a "maturing" society? International Journal of Lifelong Education, 20, 297-313.

Wlodkowski, R. J. (1999). Enhancing adult motivation to learn: A comprehensive guide for teaching all adults. Jossey-Bass, San Francisco.

Zimmerman, B. J. (1989). A social cognitive view of self-regulated academic learning. Journal of Educational Psychology, 81, 329-339.

Zimmerman, B. J. (1990). Self-regulated academic learning and achievement: The emergence of a social cognitive perspective. Educational Psychology Review, 2, 173-201. 